\title{
JEREMIAH, JUDGEMENT AND CREATION
}

\author{
Hetty Lalleman
}

\begin{abstract}
Summary
Building on a German publication by Helga Weippert, it is argued that the idea of creation can already be found in Jeremiah, not just in Isaiah 40-55. Jeremiah 4-5 has parallels in Genesis 1-2 as well as in Jeremiah 33, and there is insufficient ground to assume that Jeremiah 33 represents a post-Jeremiah development, as Weippert suggests. Jeremiah uses not only the covenant as a framework for his proclamation of judgement and doom but also creation.
\end{abstract}

\section{Introduction}

In the moral life of ancient Israel the prophets played an important role. ${ }^{1}$ In the so-called Former Prophets we see them in action in warning kings when the Ten Commandments are trespassed, for example Nathan over against David, Elijah over against Ahab. The Latter Prophets confront the people time and again with the consequences of ignoring God's commandments, the 'stipulations' provided in the framework of the covenant. As God's covenant people, Israel is required to live according to the laws of the covenant made at Sinai. But it is not only the covenant which forms the framework used by the prophets to warn the people. Creation also played a role in the preaching of judgement and repentance and in the message of the prophets in general.

In this article we will focus on the book of Jeremiah and investigate if there is a relationship between creation and covenant, in particular in the area of ethics.

1 A previous version of this paper was delivered at the Tyndale Fellowship Triennial Conference in Nantwich, 2006. 


\section{Weippert}

For many years Old Testament scholarship has been dominated by the view that the events of the Exodus and at Mount Sinai were the major themes in Israel's faith, as Von Rad stated. ${ }^{2}$ The confession of God as Creator of the universe only later became integrated into Israel's beliefs, and the Babylonian exile played an important part in establishing creation as a core belief, says the consensus view. As for the prophets, many scholars see the so-called Deutero-Isaiah as the major contributor to Israel's faith in God as the Creator of the world. The relevant chapters from the book of Isaiah are also the ones in which there is a strong emphasis on God as the Redeemer of Israel and the only God of the universe. Here idols and the worship of idols are strongly rejected and even ridiculed.

In 1981 Helga Weippert argued that Deutero-Isaiah was not the first to introduce the belief in God as the Creator. She wrote a study on Jeremiah and the belief in God as Creator entitled Schöpfer des Himmels und der Erde. Ein Beitrag zur Theologie des Jeremiabuches ${ }^{3}$ in which she tries to show that the book of Jeremiah already contains several texts which say the same as Deutero-Isaiah. Weippert relies heavily on the tool of redaction-criticism and concludes with the existence of different layers within the book of Jeremiah with regard to expressions of faith in God as Creator:

- Some verses are regarded as early-Jeremianic, such as Jeremiah $2: 13 ; 4: 23-28 ; 5: 21-25 ; 14: 19-22 ; 18: 1-12 ; 31: 31-34 ; 32: 38-40$

- Others are late-Jeremianic, such as 27:5f. and 32:27

- Passages such as 33:23-26 and 33:19-22 are considered as postJeremianic and post-exilic. ${ }^{4}$

Weippert tried to draw attention to passages about God as Creator which are dated prior to Isaiah 40-55. She sees a development within the book of Jeremiah, who in her opinion mainly emphasised God as the One who provided the rain over against Baal. God was regarded as Creator but mainly in his relationship to Israel. However, the confession of God as the Creator of the universe and of the nations

2 G. von Rad, Theologie des Alten Testaments I (München: Beck, 1978): 149-53.

3 H. Weippert, Schöpfer des Himmels und der Erde. Ein Beitrag zur Theologie des Jeremiabuches (Stuttgarter Bibelstudien 102; Stuttgart: Katholisches Bibelwerk, 1982).

4 Weippert, Schöpfer, 90. 
represents a later stage in Jeremiah's life, Weippert states, and this belief only reaches its full development after Jeremiah's lifetime. ${ }^{5}$

However, when we look closer at several of the core texts which deal with creation, it is possible to suggest a development in the proclamation of the prophet himself. ${ }^{6}$

\section{Jeremiah 5:23-25}

The first passage we look at is Jeremiah 5:23-25. These verses are part of the collection of oracles which starts at 4:5 and finishes at the end of chapter 6. They are usually dated in the early days of Jeremiah's preaching, in the time of King Josiah and King Jehoiakim. They are considered to have been part of the scroll which was read to King Jehoiakim (Jer. 36) and contain urgent invitations to repent while there is still time to avert judgement. In verses 22 and 25 we read that God has put boundaries to the sea and the waves (22) and that he provides the harvest by giving rain at set times (24). In between is verse 23 about the stubbornness of the people and their rebellious turning away from God. Verse 25 says that the 'good' has been withheld from the people because of their sins and some of those sins are spelled out in the next few verses: people abuse others in order to become rich (2627 ), the rich have ignored the most vulnerable in society, viz. the fatherless and the poor (28). What is the relationship between these social injustices and the verses about creation and the rain? ${ }^{7}$

- Verse 22 says that the sea and the waves obey the order God has set for them. They keep God's boundaries: they may roar, but they cannot transgress them.

- Verse 23 then forms a contrast: 'But this people have stubborn and rebellious hearts; they have turned aside and gone astray.'

5 Weippert, Schöpfer, e.g. 37, 62-63, 77. Note that she remains close to Von Rad.

6 The most relevant texts are Jeremiah $4: 23-28 ; 5: 21-25 ; 10: 1-18 ; 14: 22 ; 27: 5-6$; $31: 35-37 ; 32: 17$ and $27 ; 33: 1-3,19-22,23-26 ; 51: 15-19$.

7 According to Weippert, Schöpfer, 21-22, the people of God have not recognised God's work and his provision in sending rain. Also, she translates the word in

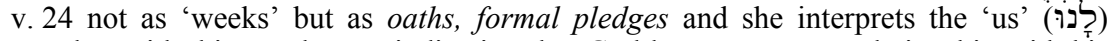
together with this word as an indication that God has a covenant relationship with his people. So in her opinion the text is only concerned with Israel as part of creation and the fact that God sustains it by giving rain, but not with the wider creation. As mentioned above, Weippert concludes that the theme of wider creation belongs to Jeremiah's later ministry and has been further developed after his lifetime. 
In other words, the sea and the waves are more sensible than 'this' (not: 'my') people. The word 'this' is used in a pejorative sense. The elements obey God's orders, but God's own people, now distanced from God due to their own wrongdoings, do not keep the boundaries God set for them. They disobey God's commandments (in the wider context of these verses they are accused of social injustice and idolatry) and they miss the 'good', which in this case probably means the rain. Their social behaviour has prevented them from receiving the good things in creation. I agree with Lundbom's comments:

The bounds transgressed are doubtless covenant demands, although Yahweh doesn't say so. ... The unruly sea keeps the bounds set for it by Yahweh. But 'this people' is like a rebellious son who disobeys parental boundaries and is unaffected by punishment. ${ }^{8}$

\section{Jeremiah 4:22-29}

Another passage in the same context as Jeremiah 5:23-25 is 4:22-29. First we concentrate on verses 23-26. The subject matter of these verses can be interpreted as the return to the chaos situation which existed before creation. Not everyone agrees with this idea, yet even if we take תהוּ רָבדו to mean emptiness and a state of 'aridness or unproductivess' without vegetation, animals and human beings, ${ }^{9}$ there seems to be good reason to make the connection with Genesis 1 and 2 . The passage reads as a reversal of the creation as described in Genesis 1 and 2, so in both accounts of creation.

8 J. Lundbom, Jeremiah 1-20 (Anchor Bible 21A; New York: Doubleday, 1999): 405.

9 See D. T. Tsumura, The Earth and the Waters in Genesis 1 and 2: A Linguistic Investigation (JSOTS 83; Sheffield: Sheffield Academic Press, 1989): 156, also 36-40. Tsumura remarks: 'Since without v. 23 there would be no reason to compare the Jeremiah passage with the Genesis creation story, we might conclude that the two single verses, Jer. 4:23 and Gen. 1:2, simply share a common literary tradition in their use of tohu wabohu, which, according to the Jeremianic context, refers to a "desertlike" state of the "earth".' (40) However, the fact that this expression occurs only in Genesis 1:2 and Jeremiah 4:23 seems important enough and is not to be ignored. In the context of the following verses, with the repetition of 'and look', there are more reminders of Genesis 1-2 than just a few words. Besides, we may assume that Jeremiah, coming from a priestly background, was familiar with the traditions of the Torah. By the same author: Creation and Destruction: A Reappraisal of the Chaoskampf Theory in the Old Testament (Winona Lake: Eisenbrauns, 2005): 28-32. 
Jeremiah 4:23-26 and Genesis 1-2 have the following elements in common: ${ }^{10}$

- ת תהו רָבדהו - Jeremiah 4:23 and Genesis 1:2

- the earth and the heavens - Jeremiah 4:23 and Genesis 1:8, $10^{11}$

- no lights - Jeremiah 4:23 and Genesis 1:3

- birds - Jeremiah 4:25 and Genesis 1:20

- no human being - Jeremiah 4:25 and Genesis 1:26; 2:5

- desert / no vegetation - Jeremiah 4:26 and Genesis 2:5

- the repeated 'I saw ... and look!' echoes the repetition of 'and God saw that it was good' in Genesis 1. Whereas the conclusion of God's creative work in Genesis is 'and God saw everything he had made and look! It was very good', the prophet says 'I saw and look! It was very bad!'

Fishbane notes that at the end of Jeremiah 4 not the Sabbath rest is mentioned, as in Genesis 1, but God's anger. ${ }^{12}$ According to the prophet, Israel's history is one of idolatry, social injustice, and disobedience of the commandments God had given. In short: 'they do not know me...' (beginning of v. 22) and, forming a chiasm with this statement, 'how to do good they know not' (end of v. 22).

This is Jeremiah's basic analysis of Israel's condition: they do not live the way the covenant relationship requires of them. The result of this is not merely a return to the days of Genesis 1 and 2, it is worse. Creation is reversed because of sin, which was absent in Genesis 1 and 2. The whole picture sounds rather apocalyptic, but when we look at the context it is the nearby judgement, in the form of war, which the prophet is announcing in the first place. ${ }^{13}$

Sin causes chaos and changes God's good creation into its opposite. Apparently the behaviour of individuals within the covenant community has cosmic effects. Creation is 'infected' by sin. Immoral behaviour has its consequences, which can be catastrophic, as this

10 These connections are based on P. C. Craigie, P. H. Kelley \& J. F. Drinkard, Jr, Jeremiah 1-25 (WBC 26; Dallas: Word, 1991): 81; M. Fishbane, 'Jeremiah iv 23-26 and Job iii 3-13: A Recovered Use of the Creation Pattern', Vetus Testamentum 21 (1971): 151-67, esp. 151-52; W. L. Holladay, Jeremiah 1 (Hermeneia; Philadelphia: Fortress, 1986): 163-68; Weippert, Schöpfer, 51; B. Maarsingh, De schepping in het Oude Testament (Kampen: Kok, 1993): 105-106; Lundbom, Jeremiah 1-20, 357-60.

11 In Jeremiah the perspective is that of the prophet; that is probably why the earth is mentioned first.

12 Fishbane, 'Jeremiah iv 23-26', 152.

13 So also Lundbom, Jeremiah 1-20, 360. 
passage points out. A connection can also be made with the story of the flood where sin has catastrophic consequences.

In the language of Jeremiah 4 there are many associations and sound effects which give this passage, when read aloud, a sense of doom,

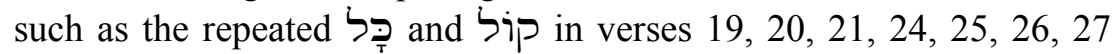
(though not the whole land will be destroyed completely, כלד) and 29 (twice at the beginning and once at the end). And there is the repeated שדד (twice in verse 20, once in 30) which expresses destruction.

Besides, the context is one of great alarm: war is coming, danger from the north, the sound of the battle cry and of the shofar is heardthere is a great range of words which express action, danger and coming disaster.

The context of Jeremiah 4 and 5 is clearly that of Israel, the people with whom God made a covenant. There are, however, some hints in the texts which remind us of other passages in the Old Testament with a wider scope. Jeremiah 5:1 asks the question if there is one honest person to be found in Jerusalem. If that were the case, 'I will forgive this city', God says. This reminds us of the pleading of Abraham for Sodom and Gomorrah in Genesis 18:16-33. In the same way the description of what happened to Sodom and Gomorrah in Genesis 19:25 (all inhabitants gone, no vegetation) shows similarities to what was described in Jeremiah 4, see also the end of verse 29: 'All the towns are deserted; no one lives in them' - an expression which recurs many times in Jeremiah.

\section{Jeremiah 33}

We saw that Weippert dates Jeremiah 5:21-25 in Jeremiah's time, whereas Jeremiah 33:19-22 and 23-26 are dated to post-Jeremianic, post-exilic times. She argues at length that a covenant with nature ('my covenant with the day and my covenant with the night') does not belong to Jeremianic thinking. She accepts that in 5:21-25 covenantlike language is use ${ }^{14}$ but thinks that there is no covenant with nature as such. The emphasis in 5:21-25 is on the covenant between God and his people, whereas the focus of 33:23-26 is on creation and the people benefit only indirectly from this covenant as a guarantee of their future, according to Weippert.

14 Weippert, Schöpfer, 21, 46. 
Besides, the idea in 33:20 that a third party would be able to break God's covenant with day and night ${ }^{15}$ is 'illogical' and is only understandable if we assume that Jeremiah's ideas about creation have already gone through a long process of tradition and adaptation, in which process ideas may have been twisted. Hence Weippert states that this is a new thought, introduced by an 'Ergänzer', who is responsible for 33:19-22 and who must be dated not earlier than the fourth century BC. ${ }^{16}$

Weippert's reasons for denying that Jeremiah 33:19-22 and 23-26 are authentic words of the historic prophet Jeremiah are open to discussion. The 'illogical' thought of 33:20 can be interpreted as deliberately illogical. Weippert herself calls it an irrealis. ${ }^{17}$ It is an impossible and illogical thought and that is exactly how it is meant: it is not possible for human beings to break the order of nature which God has laid down from the beginning. The response of the hearer or reader should be: 'But of course it is absurd to think anyone could break God's fixed order with day and night.' Through their sinful behaviour human beings can disturb the balance in nature, see Jeremiah 4-5, but it is impossible for them to completely annul the order in God's creation.

As to Weippert's suggestion that Jeremiah 33 and Jeremiah 5 differ in the role given to creation, I would argue that the concepts behind these chapters are not as far apart as she thinks. It is preferable to explain the nuances as reflecting different stages in the long ministry of the prophet himself. When we compare Jeremiah 4, 5 and 33 we can discover the following developments in concepts and language:

- 4:23-26 - the whole of creation and its order are disturbed by human beings through their sinful behaviour of idolatry and social injustice

- 5:22 - creation and nature obey God and stay within the boundaries set by him

- 5:23 - but 'this' people does not keep them

- $5: 24$ - they do not fear the one who sustains their life

- 5:25 - consequently they do not receive the 'good' because of their immoral behaviour; they 'keep the rains away' which the God of creation would provide at regular times

15 Weippert, Schöpfer, 49, keeping the lectio difficilior.

16 Weippert, Schöpfer. Jeremiah 33:19-22 is thus regarded as later than 33:23-26.

17 Weippert, Schöpfer, 48. 
- The context is one of warning and imminent judgement

- Jeremiah 33:19-22 and 23-26 are prophecies in the context of promise and restoration after exile

- They state that nothing can ever ruin God's covenant with creation which is a guarantee of God's faithfulness towards his people.

We see that the covenant with nature is an extra guarantee that God will not reject his people. Weippert says that according to Jeremiah 33 the order of creation is only indirectly beneficial to the people, ${ }^{18}$ yet in our opinion it is the main focus of the message of this passage: to reassure God's people that God's promises will be kept. In that sense nature is used in the context of the covenant between God and his people just as it was in 5:21-25. The only difference is that in a different context creation has a different function.

We can safely say that Jeremiah 5 and 33 should be interpreted as different stages of Jeremiah's proclamation. The former was spoken before God's judgement in the form of the exile broke in, the latter afterwards, when the message of the prophet had become one of promises of hope and restoration. ${ }^{19}$ The reference to the God-given order in creation supports the prophetic message in a judgement setting as well as in one of promises and hope.

There is possibly another link between 5:22, 24 and 33:20, which becomes visible when we read these verses as a reminder of Genesis $8: 22$, part of the story of Noah. There we read: 'As long as the earth endures, seedtime and harvest, cold and heat, summer and winter, day and night will never cease.' The catastrophe of the flood, when nature was completely disturbed as a result of sin (cf. Jer. 4:23-25), is over and the promise of God's lasting faithfulness is made. Whereas in Jeremiah $4-5$ the people seemed to be able to disturb his creation (although they could not ruin it completely, of course) because they did not keep the boundaries set by God, they shall keep God's boundaries in the future (31:33-34). The relationship between God and his people will be restored and be ensured forever, as unquestionably as the order in creation can never be ruined by people. ${ }^{20}$

18 Weippert, Schöpfer, 47.

19 See on this reversal of Jeremiah's message my Jeremiah in Prophetic Tradition: An Examination of the Book of Jeremiah in the Light of Israel's Prophetic Traditions (CBET 26; Leuven: Peeters, 2000): esp. 159-62.

20 B. W. Anderson, From Creation to New Creation (Minneapolis: Fortress, 1994): 31: 'It is the divine decree (hoq) that determines order (Job 38:33; Pss. 104:9; 148:6; Jer. $5: 24 ; 31: 35-36$ ), and it can even be said that Yahweh has made a covenant with the 


\section{Conclusion}

On the basis of the above we may conclude that in the book of Jeremiah there is a clear awareness of both covenant and creation. The human attitude towards the covenant even influences the fate of the created world. Besides, there appear to be links with other passages that we find in the book of Genesis as well, viz. those about the covenant with Noah and about Sodom and Gomorrah. Both of these passages are about people who are not descendants of Abraham. The fact that Jeremiah 5:23 calls Israel 'this people' suggests that at one stage they are threatened to be treated as 'just one of the nations'. In Jeremiah 33 creation is used in the context of God's unconditional promises to his people and is God's guarantee that these promises will be realised.

After considering the content and the theological themes of the passages above, my conclusion is that there are many corresponding ideas about creation in the book of Jeremiah which show coherence in structure and thought. For this reason we may doubt Weippert's idea that the belief in God as the Creator of the universe only developed after Jeremiah's lifetime. ${ }^{21}$ The strength of Weippert's work is that she pays attention to a long neglected theme in Jeremiah. More recent works do this as well, for example the recent study by Fretheim, God and World in the Old Testament.22

According to the book of Jeremiah, there is a clear relationship between moral behaviour and what happens to creation / in nature. This same relationship also occurs in other prophetic books, see Joel 1:9-10; Hosea 4:1-3 and Zephaniah 1:2-3. For Israel as God's covenant people this relationship is shown in a negative way in Jeremiah 4-5: following other gods and committing social injustice result in a situation of judgement which is close to reversing creation and the return of chaos. Fretheim is correct when he says:

day and the night (Jer. 33:20). At any moment the Creator could allow the creation to fall back into chaos, for God's continuing power is necessary to uphold and renew the creatures (Ps. 104:29-30). The regularities of nature, as mentioned in the promise to Noah (Gen. 8:22; cf. 9:13-17), are expressions of Yahweh's covenant of faithfulness.'

21 This article does not deal with texts from Hosea and Amos which show that Jeremiah's message on this subject is predated by and possibly based on these eighthcentury prophets; see Hosea 4:1-3 and Amos 4:13; 5:8 in the context of judgement. On the relations between these three prophets see my Jeremiah in Prophetic Tradition, passim.

22 Terence E. Fretheim, God and World in the Old Testament: A Relational Theology of Creation (Nashville: Abingdon, 2005). 
Because of human wickedness it does not rain $(2: 12 ; 3: 3 ; 5: 24-25 ; 14: 4)$, the land is made desolate $(12: 10-11$; see $23: 10)$, the animals and birds are swept away $(12: 4$; see $4: 25 ; 9: 10 ; 14: 5-7$; Hos. $4: 3$; Zeph. $1: 3)$, and the land is polluted $(3: 2,9 ; 16: 18$; see $2: 7$; Isa. $24: 5)$ and mourns $(12: 4$; see $4: 28$; 23:10; Isa. 24:4-7; 33:9; Hos. 4:3; Joel 1:10-20) to God $(12: 11)$. Indeed, the entire earth and heavens seem to be reduced to a pre-creation state of being $(4: 23-26)$, though that very context (v. 27) insists that no 'full end' of the earth is in view. Modern understandings of the interrelatedness of the ecosystem connect well with these biblical insights. $^{23}$

In God's creative and redeeming power, however, creation will be included in the future hope (Jer. 33:10-11) and nothing can disturb his plans to keep his promises (33:19-26). That is as certain as the Godgiven order for the day and the night.

23 Fretheim, God and World, 173. 